\title{
Formation of the Competences of Social Interaction at the Technical University
}

\author{
Nadezhda Miloradova ${ }^{1}$, and Alexander Ishkov ${ }^{1, *}$ \\ ${ }^{1}$ Moscow State University of Civil Engineering, Yaroslavskoe shosse, 26, 129337, Moscow, Russia
}

\begin{abstract}
The article is devoted to the matters of the formation of universal competences as the basis of higher technical education taking into account the requirements of the Federal State Educational Standards of Higher Education FSES HE $3+$ and FSES HE $3++$. The necessity of integration of social and humanitarian disciplines into the process of professional engineering training is proved. The authors describe their work on the development of the training course |Principles of Legislation and Social Interaction in Construction", which united the disciplines "Psychology", "Sociology", "Political science", "Law". Authors have suggested to use the concept "Me" as the key element of this course, emphasizing personal responsibility of an individual for the social interaction. The authors present the results of the comparative analyses of the progress of the students, who studied the new course and those, who studied traditional separate disciplines. They prove that the results, gained within the competence approach, are significantly better, than the results, possible in case of the use of the traditional approach.
\end{abstract}

\section{Introduction}

Higher education undergoes cardinal simultaneous changes in all respects of the structure of the educational process: (purposes and contents, technologies and organizational forms). That is the requirement of the competent approach which has succeeded explanatory-andillustrative approach. Dozens monographs and hundreds articles are devoted the competent approach. In spite of the fact that methodological and methodical development in Europe is complete (1984-2010) and daily work has begun, there are many obscure moments of current character.

Russia has begun the transformations later. Making the decision on the reform of the education system and on the accession to the uniform all-European educational space, Russia as well as some other the European countries, has chosen the way of gradual transformation. That is stated in the National doctrine of education in the Russian Federation (2000-2025) [1].

According to the analysis of foreign and domestic scientific and educational-andmethodical literature on the matters of formations of competences, first of all social-andpsychological literature, it is possible to conclude, that this matter is far from its solution.

* Corresponding author: aishkov@gmail.com 
The article considers the matters of the development of training courses on the formation of social competences, which are formulated in the Federal State Educational Standard of the higher education (FGES HE 3+) [2]. These competences have of-subject and over-subject nature, they integrate the generalized world outlook, intellectual, social, communicative, and other abilities. The nature of these competences and the condition of their formation cause a rough discussion, and also generate the greatest dispersion of opinions [3-5].

\section{Literature review}

The list of universal competences has was created in the end of the XX century within the implementation of the TUNING project ("Superstructure of the educational structures in Europe"). Then thousands of graduates, employers and hundreds of professors of various educational institutions participated in the large-scale sociological research. 30 general competences (instrumental, interpersonal and system competences) from three categories were finally selected. Respondents ranged the competences from the point of view of value of the skill for their profession and their level of development upon the completion of the program. The considerable correlation among the ratings of employers and graduates and the insignificant variability over the countries were found out: this category of respondents demanded the shift of the accents in education, giving the preference to abilities. The opinion of the professorate differed from the estimates, given both by graduates and by employers. The professorate mainly stood up for the preservation of the former approach to education: "more knowledge, less abilities". Special concern was felt by lecturers of all-humanitarian as well as social-and-economic disciplines, who had never faced the task of formation of the corresponding abilities. The research on the development of universal competences within the TUNING project continued [6]. The nature of work activity changes, some new requirements of employers to graduates appear, and that needs constant tracking and fixing [7-13].

Separate work on the matters of the higher engineering education, including the matters of the European higher construction education within the international EUCEET programme [14] is being carried out. Originally, during the Paris conference (in 2005) the discussion on the need of the training courses of over-professional orientation, supplementing construction education took place. Nobody raised doubts about the need of inclusion of the disciplines, including those of humanitarian and social character, into the educational process of training of engineers $[15,16]$. The reasons of such unanimity are obvious.

Firstly, the modern society life, in which various cultures, religions, political parties had closely intertwined, became so complicated, that it is already impossible to carry out social interaction at different levels without any social-and-communicative competence, which is understood as abilities and skills [17].

Secondly, it is impossible to refuse the humanitarian knowledge itself, which includes values, relations, interests and all those aspects give the life its unique character and also demand understanding, comprehension and judgment. The humanitarian-and-educated professional is able to make humanitarian (human) reasonable decisions when solving any problems including quite technical ones $[18,19]$.

In the previous FSES HE the competences of social-and-psychological character acted as common cultural ones. They had a strict binding to the disciplines of the all-humanitarian profile and social-and-economic profile and that allowed lecturers to realize the old programmes, constructed according to the disciplinary principles. However, universal competences do not belong to any separate discipline and cannot be created within the disciplinary approach. Development of essentially new training courses, constructed according to the modular principle is required. That is supposed that these courses will unite 
in themselves some uniform or closely related knowledge and abilities, relating to wide spheres of culture and activity [20-22].

The competent approach places emphasis on the formation of abilities and skills in all the spheres, including the social-and-humanitarian sphere. That is about the abilities to selfdevelopment and self-organization, the ability to improve the interpersonal relations, to understand and accept the variety of cultural distinctions, the abilities to work in team, to take the responsibility, to organize and manage the work in collective and so on (FSES HE $3+$ ).

The great list of common cultural competences was consolidated to seven briefly formulated categories of universal competences, which are formed throughout all the steps of higher education (bachelor degree, specialist programme, magistracy). These categories include "System and critical thinking", "Development and implementation of projects", "Team work and leadership", "Communication", "Cross-cultural interaction", "Selforganization and self-development", "Health and safety". Codes and names of the universal competences of graduates of each programme of training are registered. Thus, the authors can prove, that the problem of formation of the universal competences at the methodological level is solved, and it is possible to go to the methodical-and-pedagogical level.

But some problems are arising.

Firstly, it is obvious that any traditional discipline cannot apply for the individual formation of the universal competences. The attempt "to distribute" the competences of social interaction among such traditional disciplines as psychology, sociology, cultural science, etc., is a deadlock. Though it is still difficult to refuse such practice for the universities.

Secondly, there is the dependence of universal competences on the requirements of various professional communities, demanding accounting of specific conditions of work. In this aspect, the universal competences will differ not only in the contents, but also in structure. The competences have to be focused on the relevant competences of the experts, which are significant for the employers.

The authors recognize that the social competence as the universal competence (categories "Team Work and Leadership", "Communication", "Cross-cultural Interaction") is impossible to be created by studying separate educational disciplines of social character, out of the frames of any particular professional activity.

\section{Materials and methods}

The purpose of the research is the development of the training course, aimed on the formation of the competences of social interaction for the students, who are trained in the Construction direction (bachelor degree), as well as the assessment of this course efficiency.

The tasks of the research are the following:

1. to study the standard documents (FSES HE 3+) and to define the key indicators of the estimation of the relevant competences (indicators of the results achievement);

2. to develop the concept of the training course on the social interaction;

3. to develop the Working program and the educational-and-methodical complex (lectures, workbooks for the practical training and independent work);

4. to introduce the training course on the social interaction to the educational process;

5. to estimate the efficiency of the training course "Principles of the legislation and social interaction in construction".

The research was begun in 2015, after the adoption of the Federal state educational standard of the higher education 3+ (bachelor degree) in the "Construction" direction.

The research is being conducted in National Research Moscow State University of Civil Engineering (NR MSUCE) at the Chair of Social, Psychological and Legal Communications.

The working group of four lecturers of NR MSUCE with different basic education was created for the performance of the research. These lecturers are candidates of psychological, 
sociological, legal and technical science. The social competence has universal character, when forming it in the educational process it is impossible to forget about the inclusion of philosophical, historical, culturological and other aspects as well as some aspects of professional activity. However, that was inexpedient expand the working group during the research.

It was offered to develop the educational course "Principles of the Legislation and Social Interaction in Construction" (PLSI in construction) which would unite the disciplines Psychology, Sociology, Political science, the Law. The new integrative training course became obligatory for studying by the students of the first year.

Four common cultural competences and one general professional competence (FSES HE $3+$ ) became the basis for the course. The analysis of scientific and educational-andmethodical literature as well as the discussion in the working group, allowed to offer the following option of the key indicators for the estimation (indicators of the result achievement) and their correlation to competences (Table 1).

Table 1. The list of the planned results of training in the discipline, correlated to the planned results of the development of the educational programme.

\begin{tabular}{|c|c|}
\hline $\begin{array}{c}\text { Competence } \\
\text { according to FSES HE 3+ }\end{array}$ & Key indicators of estimation (indicators of the result achievement) \\
\hline $\begin{array}{l}\text { Ability to use the } \\
\text { principles of legal } \\
\text { knowledge in different } \\
\text { spheres of activity } \\
\text { (General competence GC- } \\
\text { 4) }\end{array}$ & $\begin{array}{l}\text { The student knows: } \\
\text { - constitutional law: its sources and principles; } \\
\text { civil law: its sources and principles; } \\
\text { - labour law: its sources and principles; } \\
\text { - } \quad \text { administrative law: its sources and principles; } \\
\text { criminal law: sources and principles; } \\
\text { - legal regulation of town-planning: its sources and principles; } \\
\text { - } \quad \text { information law: its sources and principles; } \\
\text { The student is able: } \\
\text { to define patrimonial legal status of the personality and its } \\
\text { components; } \\
\text { to analyze the employment contract from the position of the } \\
\text { labour law; } \\
\text { to use different ways of information security, relying on the } \\
\text { information law; } \\
\text { to analyze the legal situation with the conclusion of the most } \\
\text { widespread contracts: purchase-and-sale contract, rent contract, } \\
\text { works agreement; } \\
\text { to use ways of working hours accounting. } \\
\text { The student has skills: } \\
\text { of the use of the legal information resources. }\end{array}$ \\
\hline $\begin{array}{l}\text { Ability to communication } \\
\text { in oral and written forms } \\
\text { in Russian as well as } \\
\text { foreign languages for the } \\
\text { solution of the problems of } \\
\text { interpersonal and cross- } \\
\text { cultural interaction (GC-5) }\end{array}$ & $\begin{array}{l}\text { The student knows: } \\
\text { - main components of interpersonal and cross-cultural interaction; } \\
\text { problems of interpersonal and cross-cultural interaction; } \\
\text { The student is able: } \\
\text { - to use the methods of effective interpersonal and cross-cultural } \\
\text { interaction; } \\
\text { to reveal and to use psychological regularities of the } \\
\text { communication process and personal features of its participants. } \\
\text { The student has skills: } \\
\text { of the uses of modern information-and-communicative means for } \\
\text { the establishment and maintenance of interaction. }\end{array}$ \\
\hline $\begin{array}{l}\text { Ability to work in team, to } \\
\text { perceive social, ethnic, }\end{array}$ & $\begin{array}{l}\text { The student knows: } \\
\text { - types of social and cultural distinctions; }\end{array}$ \\
\hline
\end{tabular}




\begin{tabular}{|l|ll|}
\hline $\begin{array}{l}\text { confessional and cultural } \\
\text { distinctions tolerantly } \\
\text { (GC-6) }\end{array}$ & $-\begin{array}{l}\text { types of ethnic and confessional distinctions; } \\
\text { systems of cultural samples; } \\
\text { main characteristics of collective; }\end{array}$ \\
features of polycultural collective; \\
regularities of perception within the cross-cultural and \\
interpersonal interaction; \\
features of social, ethnic, confessional and cultural identity. \\
The student is able:
\end{tabular}

The social competence is the basis of human relationship. It promotes mastering of social reality and gives the chance to the person to build the behavior effectively, depending on the situation and according to the norms and standards accepted in society at the moment. The person can be considered socially competent if his or her abilities to interact meet the requirements of an interpersonal, social-and-role and economical-and-legal situation. The following levels (situations) of interaction are respectively traced: intrapersonal and interpersonal, social-and-role and social-and-legal. On the one hand, these levels are interconnected and turn one into another according to the principle of a spiral. On the other hand, they exist under their own regularities. In fact it is difficult "to dismember" the interaction into conditionally allocated levels, but that is not required according to the competent approach. As the key (system forming) element during the creation of the training course "PLSI in construction", the concept "Me" acts. Four blocks of the interaction were respectively allocated: "Me-to-Me" (intrapersonal interaction), "Me-Another one" (interpersonal interaction), "Me-Society" (social-and-role interaction) and "Me-State". At first that can seem that the emphasis on "Me" will form the egoistical relation to the social 
interaction. But actually, that it not so. The emphasis on "Me" is the emphasis on the personal responsibility of the person for the nature of social interaction, understanding of himself / herself and another/others as equal partners.

Intrapersonal interaction. It is difficult to expect adequacy of behavior from the person who cannot understand himself or herself, does not know strengths and weaknesses, is not able to operate himself or herself and appears in the condition of the intrapersonal conflict. Such person becomes a source of the conflicts and disagreements which will be demonstrated at all the levels of interaction, especially where he or she is in the active position.

Interpersonal interaction. The modern person lives in the various cross-cultural environments, interacts with "another", differing from him or her on the vital foundations, world outlook views, values and habits. According to these reasons people gain contradictions in the system of values and semantic installations, views of the world, ways of behavior, in other words: the unambiguous understanding "that it is good and that it is bad" is broken.

Social-and-role interaction. The behavior of the person, living in society is role. This concept indicates that in similar social circumstances people, various on the specific features, behave equally, in some way carrying out the given roles, realizing the external and internal stereotypes of behavior, according to the current and particular social status. This part of the training course enters the students into the situation of professional interaction, acquaints with the norms and rules, adopted in the corresponding social-and-professional environment.

Interaction of the person with the authorities "Me-State" is carried out on the recorded precepts of laws. Students gain primary legal competences, which will allow them to be guided in the legal system of Russia thanks to the following basic things: studying of the constitutional provisions, the maintenance of key branches of the law, knowledge of the norms regulating the professional sphere developments of abilities of search of professionaland-significant regulations with the use of various electronic resources of legal-and-reference systems, achievements of qualitatively new level of sense of justice and legal culture of construction branch. When developing the Working programme and educational-andmethodical materials that was decided to divide studying of the course "PLSI in Construction" into two semesters. The first module (autumn semester) is "Social Interaction in Construction" (General Competitions GC-5, GC-6, GC-7 and General Professional Competition GPC-7), the second module is "Principles of the Legislation in Construction" (GC-4). The first module (Social Interaction in Construction) is focused on the determination of competences within the multilateral social dialogue. The social competence was considered as the ability to labour (educational-and-professional) activity in the professional (educational-and-professional) environment as the readiness for the solution of problems of social interaction in construction.

The maintenance of this module has undergone some cardinal changes. The disciplinary approach, at which each discipline (Psychology, Sociology) asserted the right to be the special status as a separate independent science was completely eliminated. The specifics of the formation of social-and-humanitarian knowledge and the abilities were considered. The authors remind that the humanitarian knowledge is the separate, separate opinions, views and interpretations accepted in these or those areas (scientific, production, public, etc.). This knowledge in not formalized, it cannot be presented as the system of unambiguously recorded rules, laws and principles. It is dialog-like, its initially includes other person in communication, in which the answers to the "semantic" questions are generated. It is creative, it pushes the person on the search of a set of decisions, but not only the correct decision as it is accepted in technical fields of knowledge.

The main forms of the organization of educational process is the group project work and independent individual work. During practical training the authors offer to place the emphasis on the social interaction, on the ability to work in small group and to find the place in 
collective, on the ability to use technology of increase in cross-cultural sensitivity and communicative tolerance, etc. As the main goal for the students is to obtain the social-andpsychological, communicative and legal instruments, business games, psychological trainings, sociological researches and analysis of concrete situations became the form of carrying out classes. In other words, all the means, which proved to be adequate for the formation of abilities were used.

The second module (Principles of the Legislation in Construction) according to the Russian tradition, is focused on the Russian standards of competence, first of all such as knowledge of an object (law, etc.), abilities of their scientific explanation. During practical training students worked separate abilities of legal nature, for example, the ability to analyze contracts and legal situations in connection with various contracts and also to distinguish the nature of a problem (legal, social, psychological) that allowed to hold continuously contact of this module with the module of the social interaction.

The main form of the organization of educational process are lectures and practical trainings, with prevalence of individual work. Cases (production situations) and legal information resources were widely used as the training material.

The developed training course "Principles of the Legislation and Social Interaction in Construction" is introduced to the educational process in 2015-2016 academic year, when 50 students of NR MSUCE were trained within this course. In 2016-2017 academic year 467 students were trained within this course.

In 2017-2018 academic year 352 students started training within this course.

Performing diagnostics and the comparative analysis of results of training of those who studied according to different programmes is represented is very problematic. There is a question, how to estimate the results (what are the criteria)?

Pedagogical testing assumes to conduct the survey of residual knowledge in the strict framework of the knowledge, gained by the students. Psychological testing fixes changes in the intellectual sphere of students, their abilities to apply the gained knowledge in situations, which were not involved in the process of training. According to the traditional training the key indicator is the development of key concepts and theoretical concepts at the level of recognition (tests with the choice of possible answers). According to the competent approach the key indicator is the ability to apply knowledge for the solution of particular situations (production, social, legal, etc.). Considering these difficulties, the following evaluation criteria have been used:

1. value judgment by students and teachers;

2. academic gain score of students.

Criteria of the comparative analysis:

1. Value judgment by the students of training courses. Considering that the students, estimating their studies, usually use two criteria: interesting and useful, the authors used the 5-point scale. The minimum point -1 ; the maximum point -5 . Lectures and practical trainings were separately estimated.

2. Value judgment of teachers who were giving the studies, but did not participate in development of the training course "Principles of the Legislation and Social Interaction in Construction" was carried out according two indicators: the assessment of the Working programme and educational-and-methodical materials (1) and the attendance of occupations and the degree of activity of the students (2).

3. Academic gain scores.

Two questionnaires were respectively prepared: for the students and for the teachers. Before estimating training courses of social character, the students were asked to express their opinion on need and the importance for them such courses and also to specify what else they would like to study. In the first year of introduction of the training course (in 2015-2016) the authors carried out the comparative analysis of the students progress according to the 
results of the current control and intermediate certification with the results of those who studied according to the traditional scheme: separately training courses on Psychology, Sociology, Law.

97 students participated in the poll: two educational groups, studying "OPSI in Construction" and two groups, studying separate training courses of social orientation: Psychology, Sociology and Law. The poll was conducted in the end of the academic year after passing the exam in the corresponding course.

Only the results of the poll for students are presented in this article.

\section{Results}

The following results were obtained:

Table 2. For the Module 1. Social interaction in construction. Results are presented as percentage.

\begin{tabular}{|c|c|c|c|c|c|c|c|c|c|c|c|c|c|c|c|c|c|c|c|c|c|c|}
\hline \multirow{2}{*}{\multicolumn{3}{|c|}{$\begin{array}{c}\text { Necessity } \\
\text { of a } \\
\text { training } \\
\text { course }\end{array}$}} & \multicolumn{10}{|c|}{ interesting } & \multicolumn{10}{|c|}{ useful } \\
\hline & & & \multicolumn{5}{|c|}{ lectures } & \multicolumn{5}{|c|}{ practical training } & \multicolumn{5}{|c|}{ lectures } & \multicolumn{5}{|c|}{ practical training } \\
\hline$\stackrel{0}{\Delta}$ & \& & 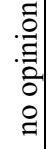 & 1 & 2 & 3 & 4 & 5 & 1 & 2 & 3 & 4 & 5 & 1 & 2 & 3 & 4 & 5 & 1 & 2 & 3 & 4 & 5 \\
\hline$\hat{\sigma}$ & 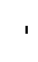 & $m$ & & & ষ & in & \pm & ' & 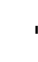 & 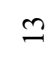 & 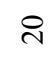 & $\widehat{6}$ & $r$ & & $\bar{\gamma}$ & 우 & $\approx$ & & ' & $m$ & 6 & $\bar{a}$ \\
\hline
\end{tabular}

Table 3. Discipline "Psychology". Results are presented as percentage.

\begin{tabular}{|c|c|c|c|c|c|c|c|c|c|c|c|c|c|c|c|c|c|c|c|c|c|c|}
\hline \multirow{2}{*}{\multicolumn{3}{|c|}{$\begin{array}{c}\text { Necessity } \\
\text { of a } \\
\text { training } \\
\text { course }\end{array}$}} & \multicolumn{10}{|c|}{ interesting } & \multicolumn{10}{|c|}{ useful } \\
\hline & & & \multicolumn{5}{|c|}{ lectures } & \multicolumn{5}{|c|}{ practical training } & \multicolumn{5}{|c|}{ lectures } & \multicolumn{5}{|c|}{ practical training } \\
\hline 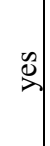 & ‡ & $\begin{array}{l}.0 \\
. \\
\vdots \\
0 \\
0 \\
\vdots\end{array}$ & 1 & 2 & 3 & 4 & 5 & 1 & 2 & 3 & 4 & 5 & 1 & 2 & 3 & 4 & 5 & 1 & 2 & 3 & 4 & 5 \\
\hline$\stackrel{-}{ }$ & , & . & & 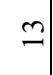 & ले & f & $\infty$ & ' & ' & & $\stackrel{\infty}{\sim}$ & $\sqrt{2}$ & ' & ' & के & $\approx$ & m & ' & ' & & $m$ & $\hat{a}$ \\
\hline
\end{tabular}

Table 4. Discipline "Sociology". Results are presented as percentage.

\begin{tabular}{|c|c|c|c|c|c|c|c|c|c|c|c|c|c|c|c|c|c|c|c|c|c|c|}
\hline \multirow{2}{*}{\multicolumn{3}{|c|}{$\begin{array}{c}\text { Necessity } \\
\text { of a } \\
\text { training } \\
\text { course }\end{array}$}} & \multicolumn{10}{|c|}{ interesting } & \multicolumn{10}{|c|}{ useful } \\
\hline & & & \multicolumn{5}{|c|}{ lectures } & \multicolumn{5}{|c|}{ practical training } & \multicolumn{5}{|c|}{ lectures } & \multicolumn{5}{|c|}{ practical training } \\
\hline$\stackrel{\tilde{D}}{2}$ & \& & $\begin{array}{l}\text { ज्ञ } \\
0 \\
0 \\
\vdots\end{array}$ & 1 & 2 & 3 & 4 & 5 & 1 & 2 & 3 & 4 & 5 & 1 & 2 & 3 & 4 & 5 & 1 & 2 & 3 & 4 & 5 \\
\hline$\infty$ & $\cong$ & 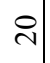 & ' & ' & $\mathcal{F}$ & nิ & 0 & 1 & $\hat{m}$ & $\stackrel{\Xi}{\sim}$ & 임 & $\sigma$ & 1 & ' & nี & ร & 0 & 1 & $\vec{\sim}$ & $\stackrel{\oplus}{m}$ & $\stackrel{\infty}{\sim}$ & $=$ \\
\hline
\end{tabular}


Table 5. For the Module 2. "Principles of the legislation in construction". Results are presented as percentage.

\begin{tabular}{|c|c|c|c|c|c|c|c|c|c|c|c|c|c|c|c|c|c|c|c|c|c|c|}
\hline \multirow{2}{*}{\multicolumn{3}{|c|}{$\begin{array}{c}\text { Necessity } \\
\text { of a } \\
\text { training } \\
\text { course }\end{array}$}} & \multicolumn{10}{|c|}{ interesting } & \multicolumn{10}{|c|}{ useful } \\
\hline & & & \multicolumn{5}{|c|}{ lectures } & \multicolumn{5}{|c|}{ practical training } & \multicolumn{5}{|c|}{ lectures } & \multicolumn{5}{|c|}{ practical training } \\
\hline$\stackrel{0}{2}$ & $\stackrel{\varrho}{\ddots}$ & 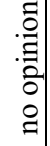 & 1 & 2 & 3 & 4 & 5 & 1 & 2 & 3 & 4 & 5 & 1 & 2 & 3 & 4 & 5 & 1 & 2 & 3 & 4 & 5 \\
\hline$\infty$ & & 2 & ' & 0 & in & $\hat{n}$ & $n$ & & & 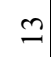 & กิ & 8 & & & 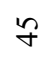 & q & 6 & & ' & $m$ & $a$ & $\begin{array}{l}\infty \\
\infty\end{array}$ \\
\hline
\end{tabular}

Table 6. Discipline "Law". Results are presented as percentage.

\begin{tabular}{|c|c|c|c|c|c|c|c|c|c|c|c|c|c|c|c|c|c|c|c|c|c|c|}
\hline \multirow{2}{*}{\multicolumn{3}{|c|}{$\begin{array}{c}\text { Necessity } \\
\text { of a } \\
\text { training } \\
\text { course }\end{array}$}} & \multicolumn{10}{|c|}{ interesting } & \multicolumn{10}{|c|}{ useful } \\
\hline & & & \multicolumn{5}{|c|}{ lectures } & \multicolumn{5}{|c|}{ practical training } & \multicolumn{5}{|c|}{ lectures } & \multicolumn{5}{|c|}{ practical training } \\
\hline$\stackrel{\mathscr{D}}{\supset}$ & ‡ & 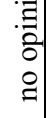 & 1 & 2 & 3 & 4 & 5 & 1 & 2 & 3 & 4 & 5 & 1 & 2 & 3 & 4 & 5 & 1 & 2 & 3 & 4 & 5 \\
\hline 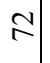 & . & $\stackrel{\infty}{\sim}$ & ' & $\stackrel{\Delta}{\sim}$ & $\mathscr{F}$ & $m$ & ' & ' & ' & $\Xi$ & $\stackrel{\infty}{-}$ & 6 & $r$ & & $\exists$ & $\stackrel{+}{+}$ & 0 & $\infty$ & F & 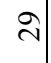 & 2 & \\
\hline
\end{tabular}

\section{Discussion}

Results of poll proves that the students have no doubts concerning the need of studying of the disciplines of social character. Moreover the vast majority supported the extension of the list of such disciplines, at least due to inclusion of various variable training courses. The students are interested in social problems of town-planning, cross-cultural distinctions, interferences of society and construction and others. They would like to master technologies of self-presentation, convincement, influence, self-organization and self-development, etc.

The criterion "usefulness" appears to be multisemantic. Firstly, it means usefulness for passing offset or an examination. If the notes of lectures helped to pass an exam in a discipline, then lectures belonged to the category «useful". Secondly, a student can consider usefulness personally for himself of herself. When estimating "Psychology" according to the criterion of usefulness, the students emphasized high usefulness of these occupations personally for themselves, but could not estimate its usefulness for their future work. Thirdly, we can consider usefulness for any profession. Students estimated usefulness of the disciplines "Sociology" and "Law" from the point of view of professional activity though they emphasized at the same time that they would prefer to invite experts for the solution of sociological and legal matters.

The "Social Interaction in Construction" module is an essentially new training course though two traditional disciplines were put in its basis: Psychology and Sociology. The maintenance of this course was interesting and useful for students. It was promoted by the relevance of the perspective and its vitality, focus on students, active forms of carrying out 
studies. In general, from the merge of psychological and sociological knowledge, both disciplines worn.

The psychology is taught in NR MSUCE for more than twenty years, and all these years this discipline attracted keen interest. There is nothing casual in the fact, as it is the only discipline within which students study themselves, improve the relations in the group, participate in trainings of personal growth. However the students estimate lectures and practical trainings differently. There is nothing surprising in that either. During the lecturers psychology is presented as the scientific discipline, having the terms framework, numerous theoretical concepts; as any other science it gives no place to everyday problems. Practical training is quite another matter. They are practice-focused, business games, cases, trainings and psychological tests are used during the practical trainings.

The sociology as a scientific discipline is taught according to the traditional approach: lectures are monological, include a lot of theoretical material such as the history of the development of sociology, sociological concepts, etc. Practical trainings are given in the form of seminars, during which students answer the questions on lecture material, makes reports on the given subjects. Such form of training was regarded by students as boring.

The discipline "Law" suffered considerable changes during the creation of the "Principles of the Legislation in Construction" module in that part which concerned practical trainings. It became practice-focused, cases containing concrete situations in construction were widely used during the practical training, students worked with legal documents directly in Internet, literal studying of separate resolutions was not required. However "Law" is difficult or "serious" discipline, like students say. The discipline demands good memory, ability to be guided in various legal literature, abilities "to read" laws and bylaws, to distinguish their status, etc. It is really difficult to listen to a lecture in which numerous legal documents are listed.

Law as a scientific discipline is taught according to the traditional approach: lectures are monological, with a lot of theoretical material. Practical trainings are given in the form of seminars during which students answer questions on the lecture material, make reports on the given subjects. Such form of training was regarded by students as boring and useless, according to them, there is no need to remember anything, which is constantly changing, and can be easily found in Internet.

\section{Conclusions}

The developed training course "Principles of the Legislation and Social Interaction in Construction" which has succeeded traditional disciplines "Psychology", "Sociology" and "Law", was highly appreciated both by students, and by teachers. The teachers noted the students activity during their trainings, their interest and efficiency of work. The results of passing a test which was carried out in the first semester and examination which was taken in the second semester were higher, than the results of similar certification of students in separate disciplines.

Problems of social interaction remain a hot subject. New Federal State Educational Standard Of Higher Education $3++$ accented this perspective and has increased its importance, having pointed out the competences of three categories: "Team work and leadership", "Communication" and "Cross-cultural interaction". The first module of the training course "Principles of the Legislation and Social Interaction in Construction" can become a basis for the creation of new training courses. There are relevant legal matters, demanding the increase in legal culture of people with the higher education, their abilities to be guided in legal matters, including those which arise to their professional sphere. The second module of the training course "Principles of the Legislation and Social Interaction in Construction" can form the basis for the creation of new training courses. 
It should be also noted that the nature of the gained knowledge within the realization of the competent approach considerably changes the traditional approaches. Students receive primary representations, learn to be guided in the theoretical concepts, master some key concepts. However the system vision of the problems, which are accumulated in the society, is not formed. Respectively there no abilities to complete understanding of the solution of these problems.

\section{Acknowledgement}

The research were carried out at National Research Moscow State University of Civil Engineering (NR MSUCE) at the Chair of Social, Psychological and Legal Communications.

\section{References}

1. Resolution of the Government of the Russian Federation of October 4, 2000 №751, https://rg.ru/2000/10/11/doktrina-dok.html

2. Order of the Ministry of education and science of the Russian Federation from March 12, 2015 №201, http://fgosvo.ru/080301.

3. N.G. Miloradova, A.D. Ishkov, MATEC Web of Conferences 106, 09009 (2017)

4. E.A. Shnyrenkov, I.P. Pryadko, Procedia Engineering 117, 325-330 (2015)

5. I.P. Pryadko, I.M. Lebedev, MATEC Web of Conferences 106, 09015 (2017)

6. Tuning Educational Structures in Europe, http://www.unideusto.org/tuningeu/

7. J.R. Garside, J.Z.Z. Nhemachena, Viewat Publisher Nurse Education Today 33(5), 541545 (2013)

8. R.M.R. Izquierdo, Revista Complutense de Educación 26(1), 81-100 (2015)

9. L.J. Shuman, R.M. Clark, S. Streiner, ASEE Annual Conference and Exposition, Conference Proceedings, 26505 (2016)

10. E. Weeks, C. Ashkar, Proceedings of the International Astronautical Congress, IAC (2016)

11. T. Bäck, L. Vallès, M. Padyab, Police Practice and Research 18(5), 478-491 (2017)

12. J. Lokhoff, Competences in Education and Recognition Project (CoRe) (Groningen and The Hague: University of Deusto, Bilbao, 2010)

13. European Civil Engineering Education and Training (EUCEET), http://www.euceet.eu/

14. E. Khripko, MATEC Web of Conferences 106, 08064 (2017)

15. A.D. Ishkov, N.G. Miloradova, MATEC Web of Conferences 106, 08068 (2017)

16. O. Gamayunova, N. Vatin, Applied Mechanics and Materials 725-726, 1640-1645 (2015)

17. E.A. Shnyrenkov, E.V. Romanova, Procedia Engineering 117, 336-341 (2015)

18. S.A. Mudrak, International Multidisciplinary Scientific Conference on SOCIAL SCIENCES and ARTS. SGEM Conference Proceedings, 131-138 (2016)

19. E. Khripko, MATEC Web of Conferences 106, 09011 (2017)

20. S.A. Mudrak, MATEC Web of Conferences 106, 09002 (2017)

21. M.G. Leontev, Procedia - Social and Behavioral Sciences 142, 695-701 (2014)

22. B.D. Ruben, International Journal of Intercultural Relations 48, 22-23 (2015) 